Brazilian Journal of Political Economy, vol. 42, $n^{\circ}$ 1, pp. 71-87, January-March/2022

\title{
Economic growth without welfare. The case of the impact of commodities on the Colombian economy
}

\author{
Crescimento econômico sem bem-estar. O caso do \\ impacto das commodities na economia colombiana
}

ANDRÉS FELIPE OVIEDO-GÓMEZ **** JUAN MANUEL CANDELO VIAFARA $\times, \times x$

\begin{abstract}
RESUMO: O crescimento econômico nem sempre está relacionado ao bem-estar social. Portanto, este artigo toma o caso da economia colombiana, que tem forte dependência da exploração de commodities, para identificar os impactos de diferentes commodities como petróleo, café, carvão e níquel sobre as variáveis econômicas. Os resultados mostram que o aumento dos preços das commodities gera impactos significativos sobre a atividade econômica em variáveis como PIB e investimento. Além disso, não há impactos significativos sobre as variáveis que proporcionam bem-estar aos indivíduos como o consumo total ou a taxa de desemprego.
\end{abstract}

PALAVRAS-CHAVE: Preços de matérias-primas; atividade econômica; comércio internacional; análise de séries temporais; modelos FAVAR; Colômbia.

ABSTRACT: Economic growth is not always related to social welfare. Therefore, this paper takes the case of the Colombian economy that has a strong dependence on commodity exploitation to identify the impacts of different commodities such as oil, coffee, coal, and nickel over economic variables. The results show that the increase in prices of commodities generates significant impacts on economic activity in variables such as GDP and investment. Also, there are no significant impacts on variables that provide welfare to individuals as total consumption or the unemployment rate.

\footnotetext{
* Ph.D.(c) student in Engineering at Universidad del Valle, Colombia. E-mail: oviedo.andres@correounivalle.edu.co. Orcid: https://orcid.org/0000-0001-9664-4684.

* Electronic Engineer at Pontificia Universidad Javeriana Cali, Colombia. Master's in applied economics at Universidad del Valle, Colombia.

x Assistant professor at Universidad del Valle, Buga and Palmira, Colombia. E-mail: juan.candelo@ correounivalle.edu.co. Orcid: https://orcid.org/0000-0002-4152-5597.

xx Business Manager at Universidad del Valle, master's in applied economics at Universidad del Valle, and Ph.D.(c) student in Management at Universidad del Valle, Colombia. Submitted: 10/January/2019; Approved: 19/April/2021.
} 
KEYWORDS: Prices of raw materials; economic activity; international trade; analysis of time series; VAR models; Colombia.

JEL Classification: F14; F41; O54.

\section{INTRODUCTION}

The boom in raw materials, which was presented in the 2000s due to the industrial growth of China and India, caused an increase of commodity prices close to $75 \%$, but a demand reduction in 2008 produced a commodity price decrease upper to $80 \%$ (International Monetary Fund, 2008). Therefore, countries like Colombia, with a high dependence on commodity exploitation for exporting, were affected. For example, Fernández, González, and Rodríguez (2015) found for Brazil, Chile, Colombia, and Peru that real income presented an average increase of $42 \%$ and the impact had an effect on economic growth, transmitted through the interest rate. However, Vargas (2015) observed negative effects on the Colombian economy such as a reduction in national income, an increased current account deficit of the balance of payments, and a depreciation of the national currency.

Therefore, countries that base their exports on commodities are more susceptible to shocks generated by the price volatility of these products. The average proportion of raw materials exported by developing countries is higher than those exported by industrialized countries (Fernández, González, and Rodríguez, 2015). For Colombia, $80 \%$ of its exports were commodities, where oil $(40 \%)$, coal $(13 \%)$, coffee $(7 \%)$, and nickel $(1 \%)$ constituted more than half of national exports (Consejo Privado de Competitividad, 2014). Accordingly, it is relevant to study the effects generated by the prices of products exported from Colombia on economic activity and to determine which are the variables that directly receive this impact.

The aim of this research is to identify the effects caused by variations in the prices of oil, coal, coffee, and nickel on Colombian economic variables. Ad hoc, it requires the use of time series models that allow establishing the duration and persistence of exogenous shocks caused by prices on different economic sectors. The methodology applied is a vector autoregressive model (VAR) proposed by Sims (1980), with a dataset that has macroeconomic series comprised in the period 2001-2016 and which summarizes the Colombian economic activity. The most outstanding results indicate significant effects on variables such as economic activity, investment, the trade balance, the real exchange rate, the external debt, and the terms of trade. However, there are no significant impacts on variables that provide welfare to individuals as total consumption or the unemployment rate.

The paper is divided into the following sections: second section reviews the literary references; third section, describes the evolution of commodities prices exported in Colombia; fourth section presents the applied methodology; fifth section, describes the dataset, and sixth section shows the results. Finally, seventh section exposes the conclusions. 


\section{LITERARY REVIEW}

Different studies have shown the commodity price variation effects over economic aggregates through the terms of trade (TOT) channel or oil price shocks. Mendoza (1995) found that the variations of TOT explain about $37 \%$ and $33 \%$ of the fluctuations of the GDP in developing countries and developed countries, respectively. However, the evidence change according to the country's economic characteristics. Spatafora and Warner (1999) determined for 18 oil-exporting countries that TOT variation's impacts on GDP, consumption, and investment were approximately $30 \%$. While, for emerging countries, Fernández, González, and Rodríguez (2015) observed significant effects on economic cycles, GDP, investment, consumption, and real exchange rate (RER). Also, Schmitt-Grohé and Uribe (2015) and Broda (2004) identified a variation of around $10 \%$ on production, consumption, and investment.

On the other hand, Latin American commodity exports were upper than $60 \%$ in 2014. Hence, these economies are more suceptible to receive commodity price shocks. For different South American countries such as Brazil, Mexico, Chile, Colombia, Ecuador, Argentina, and Peru, the TOT fluctuation generated effects on production, GDP growth, and government consumption (Ben-Zeev, Pappa, and Vicondoa, 2016; Ahmed, 2003; Izquierdo, Romero, and Talvi; 2008; Medina, 2010). Besides, Castillo and Salas (2010) for Peru and Peña $(2008$; 2015) for Venezuela found that variables such as GDP, employment rate, consumption, and investment, were impacted by commodity price variations.

In the Colombian economy, the response of commodity price and oil price variations generated effects on production, investment, the real exchange rate, and inflation. Oviedo-Gómez and Sierra (2019) and Oviedo-Gómez and Candelo (2020), based on a FAVAR model, observed that TOT and energy commodity variations generated effects on economic activity, the balance of trade, and RER. Further, the authors determined that the investment had a variation of around 8\%. Hernández (2013) found that TOT fluctuations generated impacts on GDP by approximately $27 \%$ and $33 \%$. On the other hand, Poncela, Senra, and Sierra (2017) observed a positive relationship among RER, manufacturing production, and commodity prices. This research empirically tests the hypothesis of Corden (1984), who explains the causes of the dollar devaluation in Colombia by the increase in the raw material prices. In addition to TOT shocks, the oil price shocks generate significant effects on the Colombian economy. Gómez (2015) and González and Hernández (2016) observed positive responses of GDP, TOT, the balance of trade, foreign investment, and CPI, and negative responses of RER and external debt by a positive shock of oil prices. While Uribe and Ulloa (2011) found a negative and significant effect on national unemployment. For the department of Valle del Cauca, which is characterized by a high level of industrialization and a small dependence on the mining-energy sector, Candelo (2018) determined that an increase in oil prices generates a slowdown in regional GDP, that deteriorates consumption due to the high foreign income.

Despite the evidence found in empirical studies, this research seeks to identify 
if the commodity price shocks generate social welfare through variables such as consumption and employment.

\section{THE COLOMBIAN ECONOMY AND COMMODITY DYNAMICS}

Sinnott, Nash, and De la Torre (2010) observed the effects of commodity price fluctuations were captured in economies with high mining-energy commodities exploitation. Figure 1 shows the production of raw materials (bar with weft) and other goods (bar with filling) exported per year as a proportion of total national exports from 1980. It observes that the proportion of the raw materials exported during the last three decades is higher, even though the Colombian production of non-traditional goods predominated until the 2000s when raw materials returned to increase their weight within the most exported products.

Figure 1: Production of commodities and other goods exported as a total proportion of exports in Colombia for 1980-2016

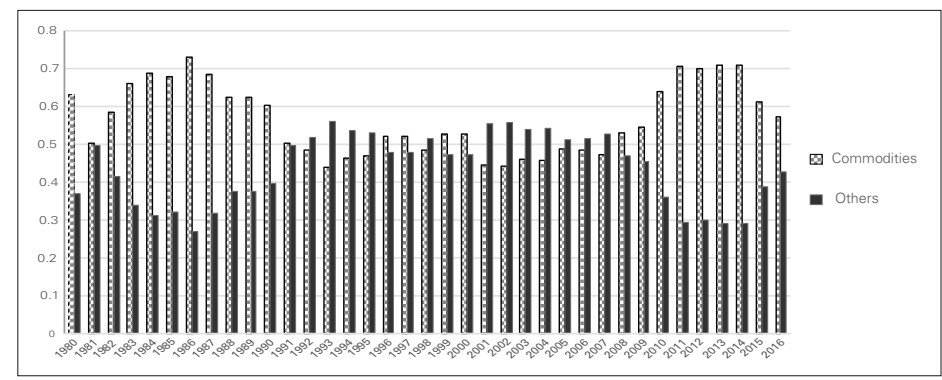

Source: Banco de la República (2020).

On the other hand, Figure 2 describes the monthly prices of oil ${ }^{1}, \mathrm{coffee}^{2}, \mathrm{coal}^{3}$, and nickel ${ }^{4}$ in Colombia for the timespan 1980-2016. Firstly, from 1970 to 2000 the coffee was the most important product for exporting in Colombia, it represented around $50 \%$ of total exports (Cano, Vallejo, Caicedo, Amador, and Tique, 2012).

\footnotetext{
${ }^{1}$ Oil prices are taken from: simple average of three spot prices; Dated Brent, WTI and Dubai Fateth.

${ }^{2}$ Coffee prices are taken from: soft Arabic coffees, cash prices from the International Coffee Organization, New York. US\$ cents per pound Oil prices are taken from: simple average of three spot prices; Dated Brent, WTI and Dubai Fateth.

${ }^{3}$ Coal prices are taken from: Australian term coal, 12,000 btu / lb, less than $1 \%$ sulfur, $14 \%$ ash, FOB Newcastle / Port Kembla, US\$ per metric ton. Coffee prices are taken from: coffees soft arabica, cash prices from the International Coffee Organization, New York. US \$ cents per pound. Oil prices are taken from: simple average of three spot prices; Dated Brent, WTI and Dubai Fateth.

${ }^{4}$ Nickel prices are taken from: nickel, merger grade, LME spot price, European CIF ports, US\$ per metric ton.
} 
However, from 2000 the oil increased its weight in total exports and has been the most important mining-energy good for Colombia.

The prices of the other exported raw materials, coal and nickel, show similar dynamics to oil prices, i.e., the trend of coal and nickel prices increased since 2000, due to the high demand for commodities in Asian countries. However, after 2008 these prices have dropped significantly. According to Oviedo-Gómez and Candelo (2020), the correlation between commodity prices and economic variables in Colombia shows a positive and high relation among oil, coal, and nickel prices and GDP, investment, and the trade balance. However, they observed a negative and high relation among these prices and RER and inflation.

Therefore, Oviedo-Gómez and Sierra (2019), Oviedo-Gómez and Candelo, and Hernández (2013) observed significant response of GDP, investment, the balance of trade, and RER in Colombia, but is important to determine if a positive shock of commodity prices produces social welfare, besides generating economic growth.

Figure 2: Oil, coffee, coal, and nickel price dynamics for the period 1980-2016

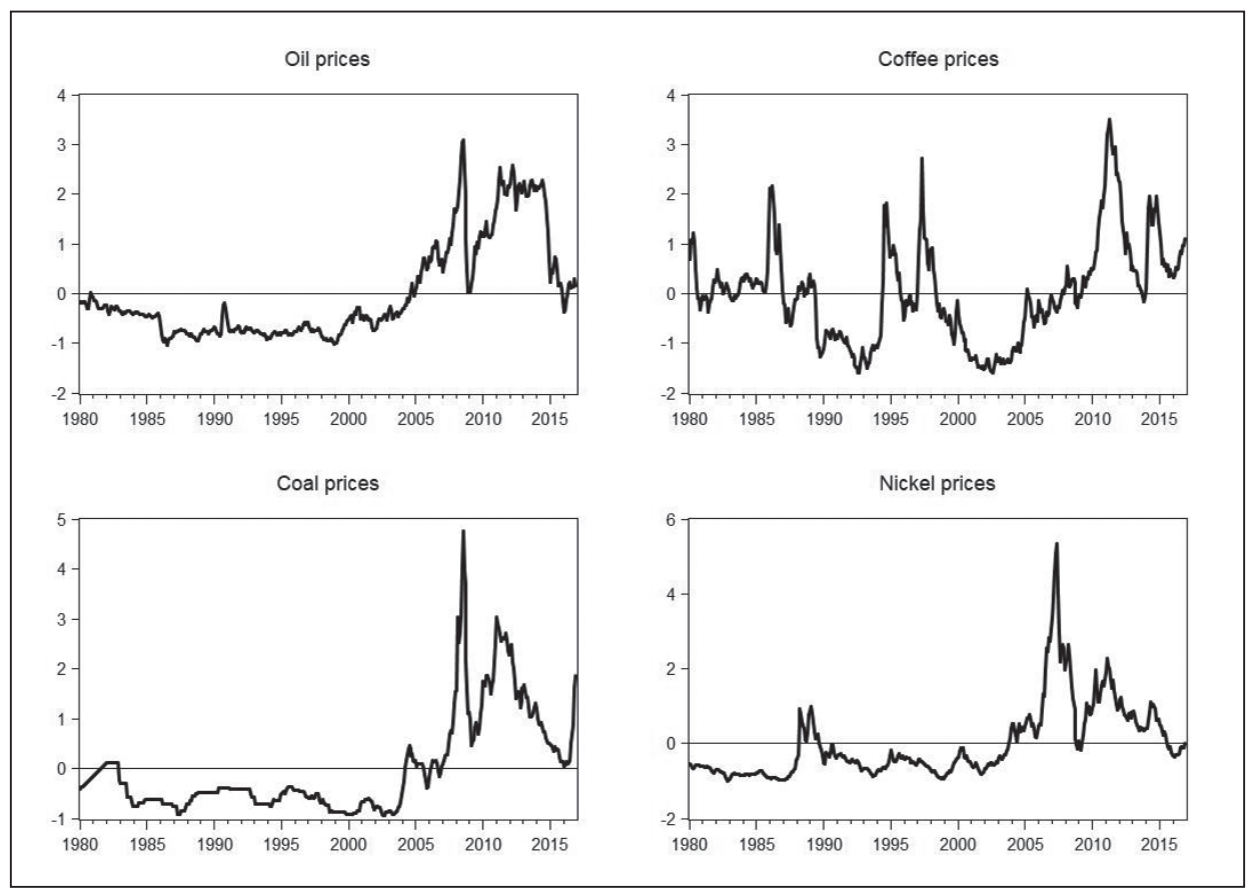

Source: IMF

\section{METHODOLOGY}

The empirical methodology applied to identify the effects of the four commodity price shocks with a higher weight in national exports is described below. The VAR 
methodology proposed by Sims allows analyzing the temporal persistence of innovations by estimating Impulse-Response Functions (IRF) and solve the endogeneity problem. The model can be written through a reduced equation system and matrix form to observe how the shocks affect the variables.

\section{VAR model}

We start from equation (1) and (2) to exemplify a first order VAR, where $u_{t}$ and $z_{t}$ are $\mathrm{I}(0)$ variables and where the errors $\varepsilon_{u t}$ and $\varepsilon_{z t}$ are shocks represented by a white noise process with zero mean and variances $\sigma_{\varepsilon_{u t}}^{2}$ and $\sigma_{\varepsilon_{z t}}^{2}$ constants. The model is written as the following system of equations:

$$
\begin{aligned}
& u_{t}=\alpha_{11}+\alpha_{12} z_{t}+b_{11} u_{t-1}+b_{12} z_{t-1}+\varepsilon_{u_{t}} \\
& z_{t}=\alpha_{21}+\alpha_{22} u_{t}+b_{21} u_{t-1}+b_{22} z_{t-1}+\varepsilon_{z_{t}}
\end{aligned}
$$

The result is a model of simultaneous equations with the particularity of its variables being endogenous. In matrix form, the VAR model can be written in this way:

$$
\begin{aligned}
& {\left[\begin{array}{cc}
1 & \alpha_{12} \\
\alpha_{22} & 1
\end{array}\right]\left[\begin{array}{l}
u_{t} \\
z_{t}
\end{array}\right]=\left[\begin{array}{l}
\alpha_{11} \\
\alpha_{21}
\end{array}\right]+\left[\begin{array}{ll}
b_{11} & b_{12} \\
b_{21} & b_{22}
\end{array}\right]\left[\begin{array}{l}
u_{t-1} \\
z_{t-1}
\end{array}\right]+\left[\begin{array}{l}
\varepsilon_{u_{t}} \\
\varepsilon_{Z_{t}}
\end{array}\right]} \\
& \alpha Y_{t}=\Gamma_{0}+\Gamma_{1} Y_{t-1}+\epsilon_{t} \\
& y_{t}=B_{0}+B_{1} y_{t-1}+\epsilon_{t}
\end{aligned}
$$

Where the vector $y_{t}$, of $M \times 1$ dimensions, is constituted by economic variables: oil prices (or coffee prices, among others), product, investment, balance of trade, exchange rate, consumption, and inflation, for a $t=1,2 \ldots T$ periods.

\section{DATA}

The database used for this research was a balanced panel of quarterly data for the timespan 2001-2016. The variables were GDP, investment, the balance of trade, RER, inflation, total consumption, the unemployment rate, TOT index, and external debt. Besides, oil, coal, nickel, and coffee prices. Table 1 summarizes the variables and their sources: Banco de la República (BR), the National Administrative Department of Statistics (DANE), the Ministry of Finance and Public Credit (MH), and the International Monetary Fund (IMF). 
Table 1: Description of variables

\begin{tabular}{|l|c|}
\hline \multicolumn{1}{|c|}{ Variable } & Source \\
\hline GDP & DANE \\
\hline Investment & DANE \\
\hline The balance of trade & BR \\
\hline Real exchange rate (RER) & BR \\
\hline Inflation & BR \\
\hline Total consumption & DANE \\
\hline The unemployment rate & BR \\
\hline Terms of trade index (TOTi) & BR \\
\hline External debt (Millions of pesos) & MH \\
\hline Oil prices & IMF \\
\hline Coal prices & IMF \\
\hline Coffee prices & IMF \\
\hline Nickel prices & IMF \\
\hline
\end{tabular}

Source: Authors' own elaboration.

Besides, the series were reviewed one by one to eliminate outliers, because these can be considered as errors (Stock and Watson, 1998). The atypical data were omitted, through the program TRAMO (Time-series Regression with ARIMA noise, Missing values, and Outliers), developed by Gómez and Maravall (2001) that estimates a univariate ARMA model to find the outliers. On the other hand, the unit root test with intercept and trend was applied using the tests suggested by Dickey and Fuller (1979) and Phillips and Perron (1988). Finally, the variables, after being converted to stationary, are standardized with mean equal to zero and variance equal to one, following Stock and Watson (2011). In summary, the variables were transformed by the first difference of the logarithm.

\section{EMPIRICAL RESULTS 5}

The results of the VAR model estimation described by equation (5) and proposed by Sims (1980) are presented below. This section is divided into the Impulse-response Functions (IRF) and variance decomposition estimation.

\section{Impulse-Response Function (IRF)}

For equation (5), the vector $y_{t}$ contains the following variables: oil prices $\left[O P_{t}\right]$ or coffee prices $\left.\left[\mathrm{CoP}_{t}\right]\right]$, or coal prices $\left.\left[\mathrm{CP}_{t}\right]\right]$, or nickel prices $\left.\left.\left[N P_{t}\right]\right]\right)$, GDP $\left[G P D_{t}\right]$,

\footnotetext{
${ }^{5}$ The software used to FAVAR model estimation was EVIEWS 9.
} 
investment $\left[I_{t}\right]$, RER $\left.\left[R E R_{t}\right]\right]$, the balance of trade $\left.\left[B C_{t}\right]\right]$, inflation $\left[N P_{t}\right]$, TOTi $\left.\left[T O T_{t}\right]\right]$, and the unemployment rate $\left.\left[U R_{t}\right]\right]$. The second estimated model replaces the GDP by total consumption $\left[C_{t}\right]$, given that the economic activity is explained by consumption. Besides, the unemployment rate is replaced by external debt $\left[E D_{t}\right]$. The models estimated and described below had a time length of two lags and the generalized and accumulated IRF are estimated for a confidence interval of $95 \%$ and a period of 15 quarters $^{6}$. Therefore, equation (5) can be written as:

$$
\begin{gathered}
y_{t}=B_{0}+B_{1} y_{t-1}+\epsilon_{t} \\
y_{t}^{\prime}=\left[O P_{t}, G P D_{t}, I_{t}, R E R_{t}, B C_{t}, I N_{t}, T O T_{t}, U R_{t}\right]
\end{gathered}
$$

\section{Impact of oil prices}

The variable response of a positive shock of oil prices is shown in Figure 3 and Figure 4. It observes a positive and significant effect on GDP, with a duration of approximately one quarter, and on investment with a duration of two quarters in different periods. On the other hand, and due to the high dependence of the national economy on oil, it is found that the shock causes a positive and significant impact on national aggregate demand, which consequently generates a positive and significant impact on the trade balance for eight periods. Besides, OviedoGómez and Sierra (2019), Oviedo-Gómez and Candelo (2020), and Hernández (2013) identified that the positive variation on investment is given indirectly through the fluctuations of the balance of trade, which causes income increases and then on investment.

Also, it is observed a negative and significant effect on the RER, with an approximate duration of three quarters. The high entrance of dollars to the Colombian economy generates a dollar devaluation and a peso appreciation by positive oil price shock. Besides, the TOT responds positively and significative to oil price fluctuation. On the other hand, given the relationship between the trade balance and the external debt, due to the increase in exports, the trade balance is less deficit, which reduces international indebtedness (see Figure 4). Finally, it is observed no significant impact on the unemployment rate and total consumption. Parra (2008) and Oviedo-Gómez and Sierra (2019) found that increases in oil prices do not generate an inflationary process, i.e., the inflation does not depend on external shocks and it does not modify the consumption dynamics.

\footnotetext{
${ }^{6}$ Appendix A shows the residuals tests for each model estimated.
} 
Figure 3: Impulse-Response of GDP, investment, RER, the trade balance,

TOTi, and the unemployment rate to oil price shock

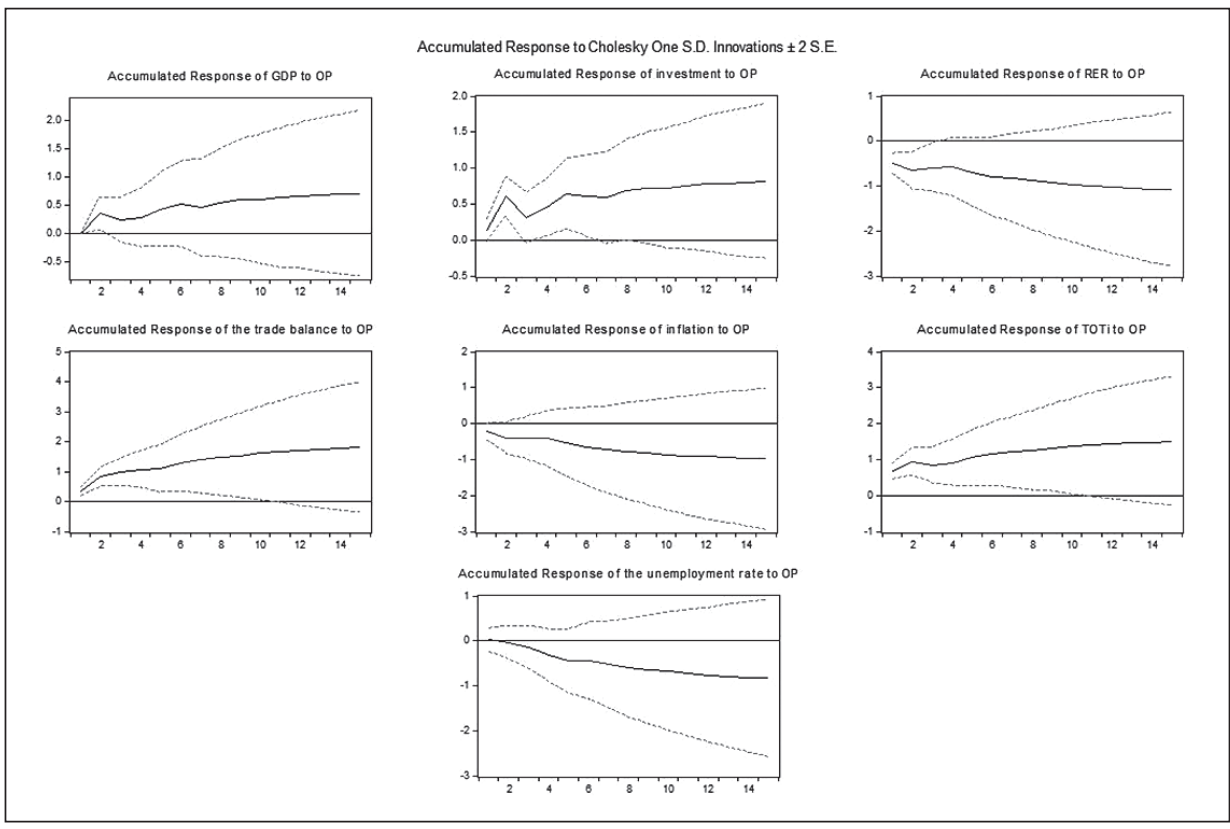

Source: Authors' own elaboration.

Figure 4: Impulse-Response of total consumption and external debt to oil price shock

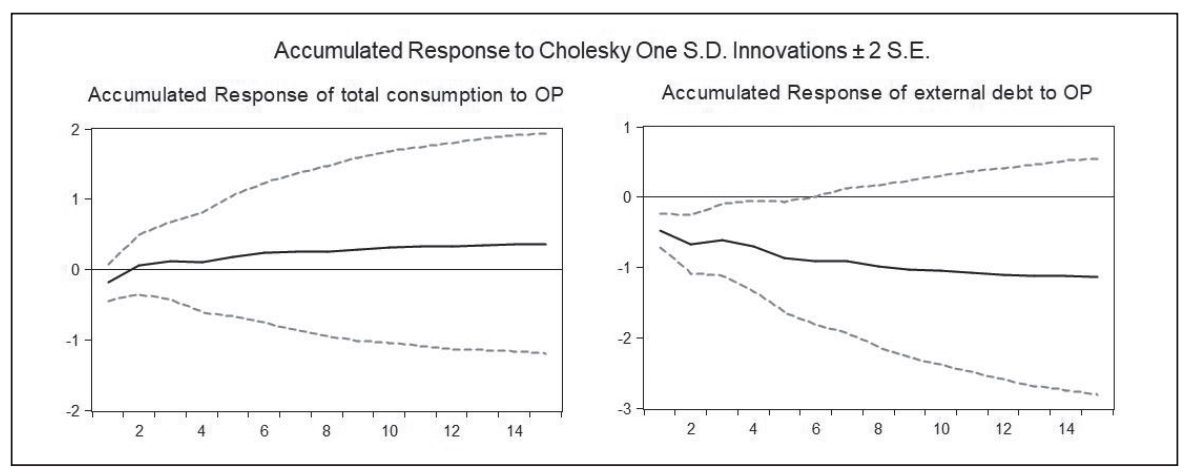

Source: Authors' own elaboration.

\section{Impacts of coffee prices}

Figure 5 and Figure 6 describe the results of coffee price shock over the variables. A positive shock generates a positive and no significant response to economic activity, investment, and inflation. On the other hand, an increase in coffee prices produces a positive and significant impact on the trade balance and the terms of trade for five and four periods, respectively. The reason for these positive responses is the 
increment in the national production of exported goods (Oviedo-Gómez and Sierra, 2019). Likewise, it observes a dollar devaluation due to the high income of the North American currencies after the increase in coffee exports, where the effect is significant on the RER for the first four periods after the impact (Sierra and Manrique, 2014; Peláez and Sierra, 2016). Further, it observes that the increase in the trade balance generates a negative and significant impact on external debt. Finally, the variations in total consumption and the unemployment rate are not significant.

Figure 5: Impulse-Response of GDP, investment, RER, the trade balance,

TOTi, and the unemployment rate to coffee price shock

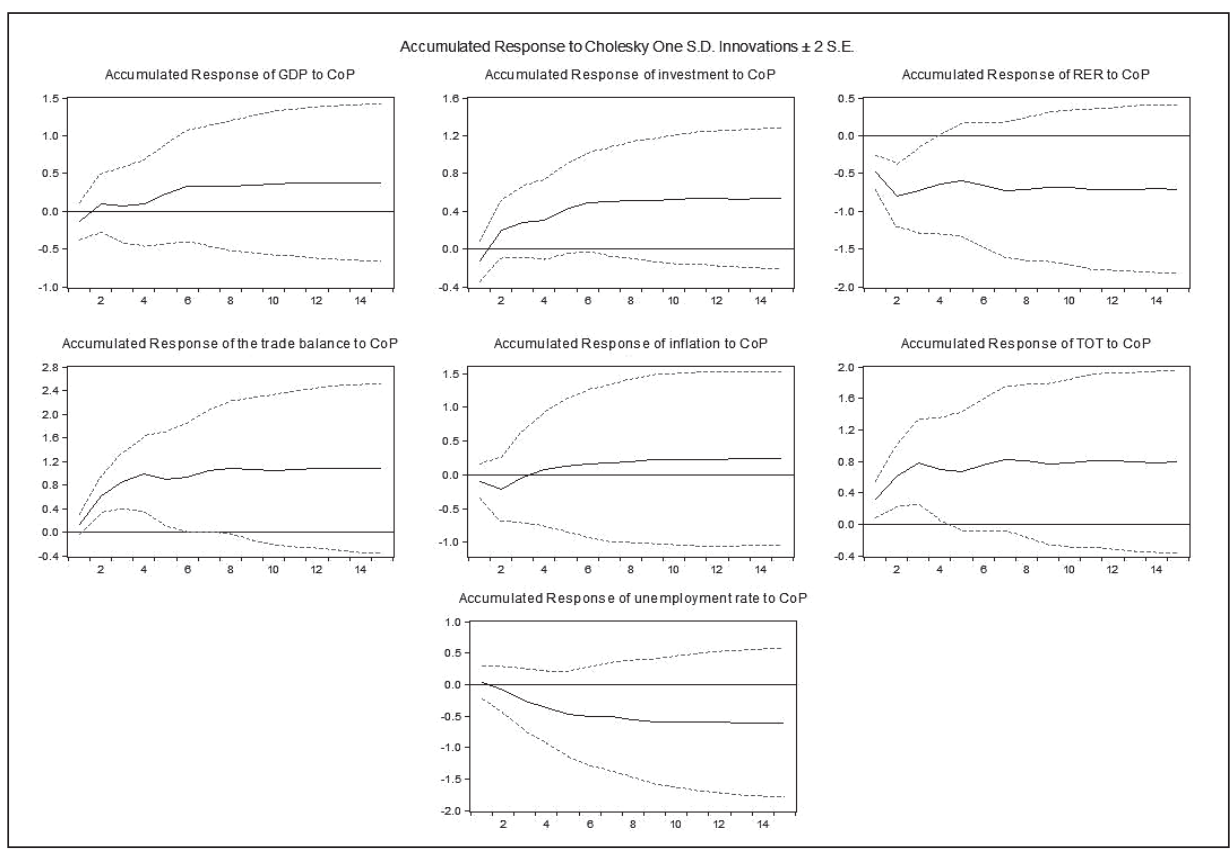

Source: Authors' own elaboration.

Figure 6: Impulse-Response of total consumption and external debt to coffee price shock

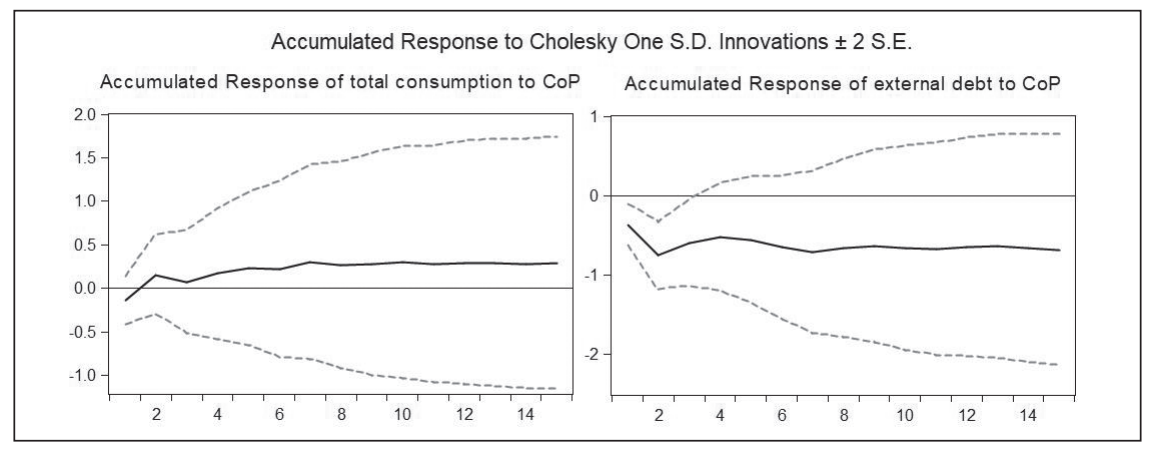

Source: Authors' own elaboration. 


\section{Impact of coal prices}

On the other hand, the coal price innovation effects, which can be observed in Figure 7 and Figure 8, show a significant impact on the trade balance, TOT, RER, and the external debt. However, GDP, investment, the unemployment rate, inflation, and total consumption do not show a significant response after the shock. In summary, an increase in coal prices increases exports, the trade balance, and TOT, thus the inflow of foreign currency increases, and foreign debt decreases. On the contrary, there is no evidence of a significant impact on investment and the employment rate since the exploitation of coal does not require high levels of investment or labor (Oviedo-Gómez and Candelo, 2020).

Figure 7: Impulse-response of GDP, investment, RER, the trade balance, TOTi, and the unemployment rate to coal price shock

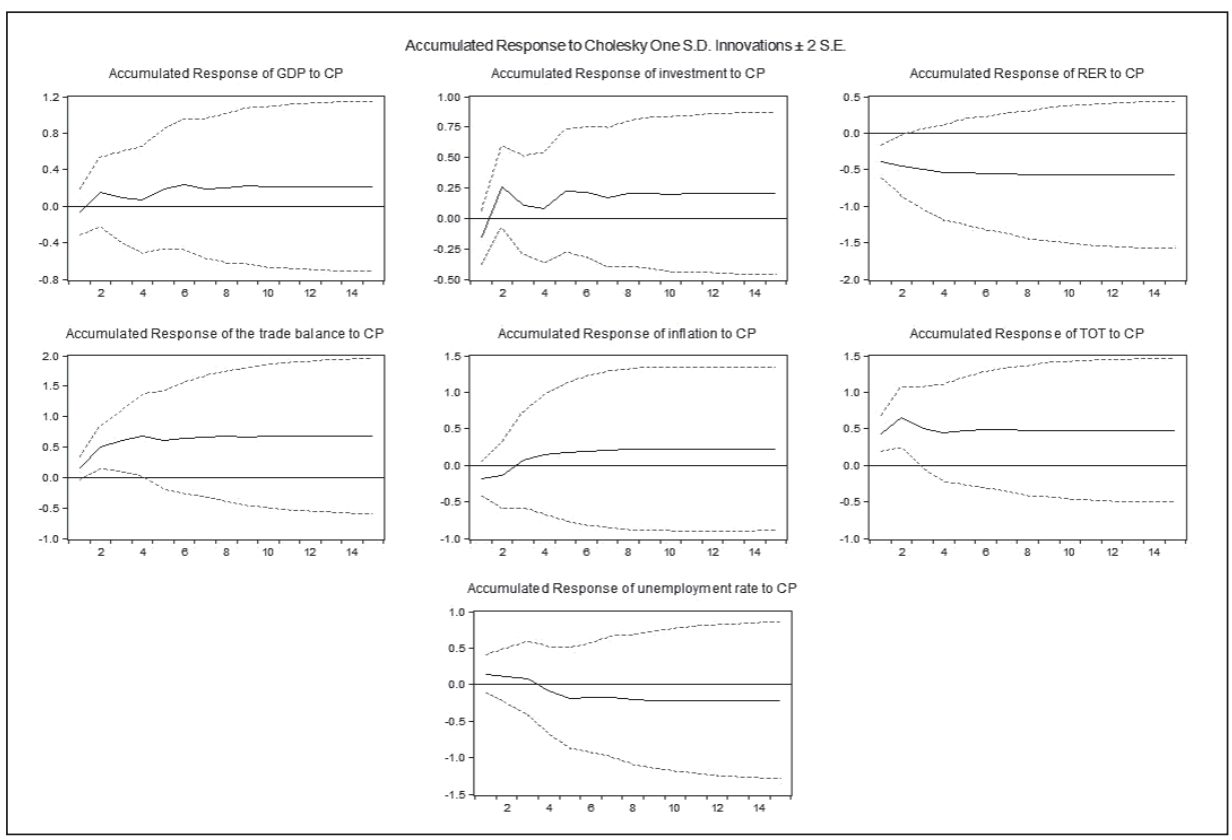

Source: Authors' own elaboration. 
Figure 8: Impulse-Response of total consumption and external debt to coal price shock

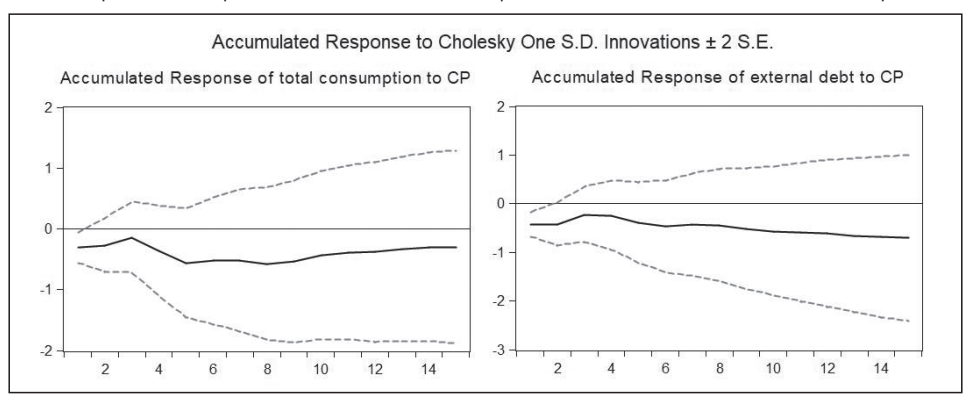

Source: Authors' own elaboration.

\section{Impact of nickel prices}

The effects of nickel prices are described in Figure 9 and Figure 10. A positive impulse of nickel prices like coffee and coal does not generate significant impacts on GDP. On the other hand, there are positive and significant effects on the trade balance, and it observes an international debt decrease caused by exports increase. Besides, the peso appreciation produces a negative response to RER. Likewise, it identified in TOT and the trade balance increase by the direct correlation between the price of nickel in this index (Oviedo-Gómez and Sierra, 2019). However, investment, total consumption, and the unemployment rate do not present significant changes.

Figure 9: Impulse-Response of GDP, investment, RER, the trade balance, TOTi, and the unemployment rate to nickel price shock.

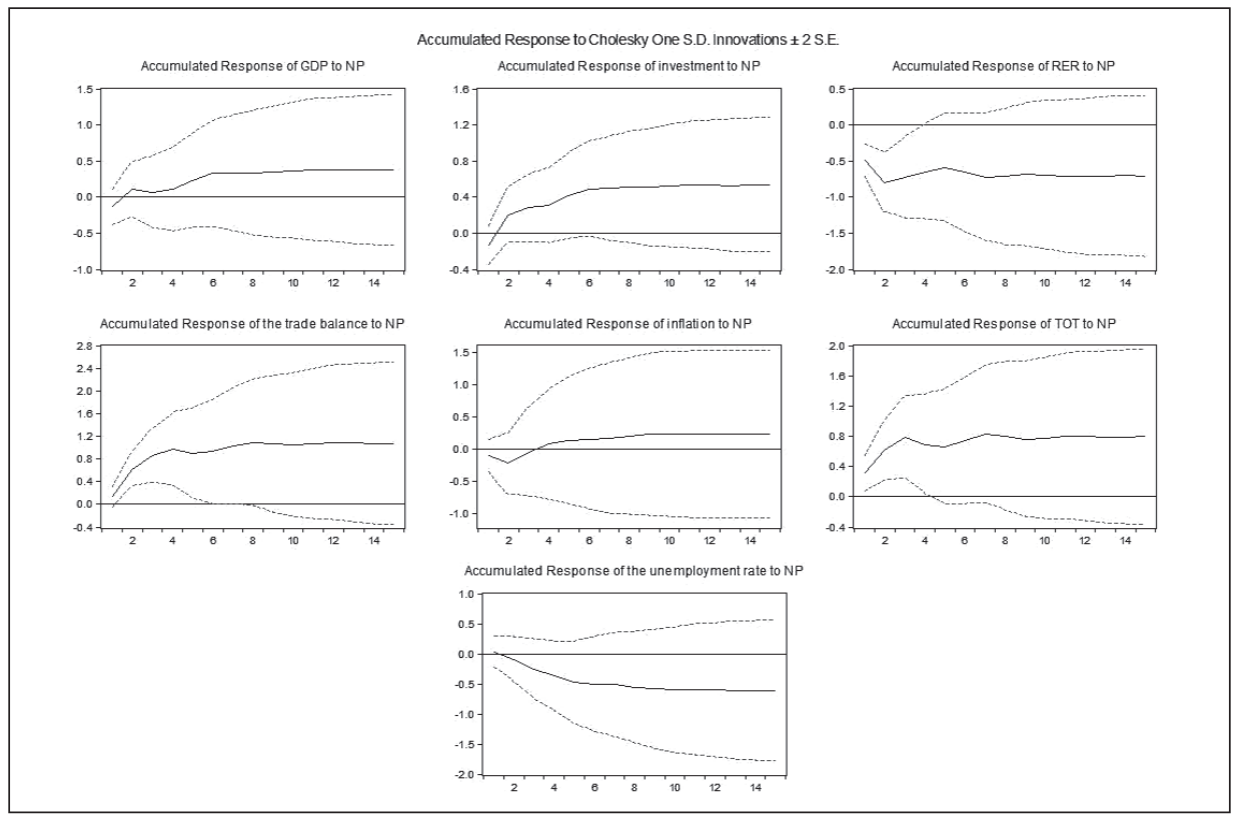

Source: Authors' own elaboration. 
Figure 10: Impulse-Response of total consumption and external debt to nickel price shock

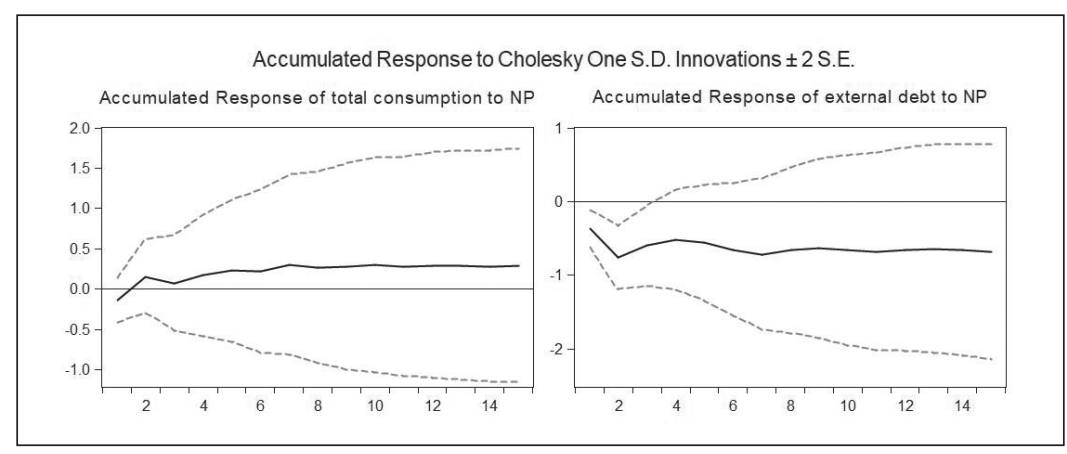

Source: Authors' own elaboration.

The income of a population is related to consumption levels that generate social welfare (UNDP, 2014). Similarly, the level of employment in a developing economy, which has markets with high rates of unemployment and informal work, reflects the difficulty of individuals to acquire income (Arias, Mayorga, and Magrinyá, 2019). Therefore, a positive price impact of some commodities such as oil, coffee, coal, and nickel on economic activity, generates an insignificant response on variables such as consumption and employment that are related to social welfare. Hence, these show a disparity between economic growth and social welfare.

\section{Decomposition of variance}

The variance decomposition allows modeling the proportion of movements of a variable from its innovations and the effects it generates on other series of the model. Therefore, the variance decomposition captures the different components that manage to isolate the variability percentage of each series that is produced by the shock, to recognize the relative dependence that the variable has on the others. The orthogonalization method of Cholesky ${ }^{7}$ is used to orthogonalize the VAR residuals.

Table 2 shows the variance decomposition for a finite horizon of 20 periods. GDP presented a variation between $0.6 \%$ and $1.4 \%$, investment presented a variation between $1.6 \%$ and $5.5 \%$. Likewise, the RER may be affected between $1.4 \%$ and $3.3 \%$. The trade balance presented oscillations between $0.6 \%$ and $8.9 \%$. Inflation is between $2.2 \%$ and $6.8 \%$ and TOT is between $2.3 \%$ and $10.8 \%$. The unemployment rate is between $0.9 \%$ and $1.8 \%$ and total consumption between $0.6 \%$ and $8 \%$. Finally, external debt is between $1.8 \%$ and $5.3 \%$.

\footnotetext{
${ }^{7}$ The decomposition of Cholesky requires the ordering of variables according to their degree of contemporary endogeneity. The variables are organized from the most endogenous to the most exogenous.
} 
Table 2: Variance decomposition of variables

\begin{tabular}{|l|c|c|c|c|}
\hline & \multicolumn{4}{|c|}{ Percentage of variance explained by commodity prices } \\
\hline Variables & Oil prices & Coffee prices & Coal prices & Nickel prices \\
\hline GDP & 1.2 & 1.4 & 0.8 & 1.4 \\
\hline Invesment & 2.8 & 5.5 & 1.6 & 5.5 \\
\hline RER & 1.4 & 3.4 & 2.6 & 3.3 \\
\hline The trade balance & 3.6 & 8.9 & 0.6 & 8.9 \\
\hline Inflation & 6.8 & 2.2 & 4.6 & 2.2 \\
\hline TOT & 4.0 & 10.8 & 2.3 & 10.8 \\
\hline $\begin{array}{l}\text { The } \\
\text { unemployment } \\
\text { rate }\end{array}$ & 0.9 & 1.8 & 1.7 & 1.8 \\
\hline Total consumption & 0.6 & 3.8 & 8.0 & 3.8 \\
\hline External debt & 1.8 & 5.3 & 6.0 & 5.3 \\
\hline
\end{tabular}

Source: Authors' own elaboration.

\section{FINAL COMMENTS}

The aim of this research was to identify the effects of the commodity price variations in Colombian over different economic aggregates, principally on the total consumption and the unemployment rate because these variables are an approximation of social welfare. For this, we used the VAR models proposed by Sims, which allowed us to understand the impact of raw materials exported by Colombia on economic activity. We used a dataset that has a macroeconomic series comprised in the period 2001-2016. Therefore, the contributions of this article are, first, understanding the response of an economy that produces commodities to the impact of these prices and second understanding how fluctuations in the prices of raw materials affect social welfare.

The effects on the economy by commodity price fluctuations show a significant response on GDP and investment, which mostly focuses on the oil sector due to its profitability. Consequently, there is an increase in national exports that decreases the trade deficit and external debt. On the other hand, the commodity sector boom produces a revaluation of the Colombian peso due to the increase in foreign currency inflows. Besides, this research shows signs that there is not a benefit on the activity of the mining sector and on other indicators such as the unemployment rate and total consumption, which are fundamental for improving the welfare of an economy. Therefore, this raises some questions about the resource focus in the commodity sector, and despite that evidence shows the economic improvement at the aggregate level, it does not observe an improvement in fundamental variables that contribute to sectors such as the manufacturing industry and the services sector. These variables are, for example, labor-intensive that would allow economic growth with less dependence on variables exogenous. 


\section{REFERENCES}

Ahmed, S. (2003). Sources of economic fluctuations in Latin America and implications for choice of exchange rate regimes. Journal of Development Economics, 72(1), 181-202.

Banco de la República. (2020). Exportaciones. Bogotá, Colombia: Banco de la República. Recuperado de https://www.banrep.gov.co/es/ estadisticas/exportaciones

Bai, J., \& Ng, S. (2002). Determining the number of factors in approximate factor models. Econometrica, 70(1), 191-221.

Ben-Zeev, N., Pappa, E., \& Vicondoa, A. (2016). Emerging Economies Business Cycles: The Role of the Terms of Trade Revisited. Ben-Gurion University of the Negev, (1610).

Broda, C. (2004). Terms of trade and exchange rate regimes in developing countries. Journal of International economics, 63(1), 31-58.

Candelo, J, M. (2018). Impactos indirectos de la tasa de cambio y los precios del petróleo en una economía no petrolera: aproximaciones VECM y VAR para el Valle del Cauca, Colombia. Finanzas y Política Económica, 10(2), 403 - 436.

Cano, G., Vallejo, C., Caicedo, E., Amador, J., \& Tique, E. (2012). El mercado mundial del café y su impacto en Colombia. Banco de la República, (710), 1-57.

Castillo, P., \& Salas, J. (2010). Los términos de intercambio como impulsores de fluctuaciones económicas en economías en desarrollo: Estudio empírico. México DF: México. Centro de Estudios Monetarios Latinoamericanos.

Consejo Privado de la Competitividad (2014). Informe nacional de competitividad 2014-2015. Bogotá: Consejo Privado de Competitividad.

Corden, W. M. (1984). Booming sector and Dutch diseaseeconomics: Survey and consolidation. Oxford Economic Papers, 36(3), 359-380.

Dickey, D. A., \& Fuller, W. A. (1979). Distribution of the estimators for autoregressive time series with a unit root. Journal of the American statistical association, 74(366a), 427-431.

Fernández, A., González, A., \& Rodríguez, D. (2015). Sharing a Ride on the Commodities Roller Coaster: Common Factors in Business Cycles of Emerging Economies. Banco de la República, (014054).

Fondo Monetario Internacional. (2008). Housing and the Business Cycle, World Economic Outlook. (08).

Forni, M., Hallin, M., Lippi, M., \& Reichlin, L. (2000). The generalized dynamic-factor model: Identification and estimation. The review of Economics and Statistics, 82(4), 540-554.

Forni, M., Hallin, M., Lippi, M., \& Reichlin, L. (2005). The generalized dynamic factor model: one-sided estimation and forecasting. Journal of the American Statistical Association, 100(471), 830-840.

Geweke, J. (1976). The dynamic factor analysis of economic time series models. University of Wisconsin, 22(1), 37-54.

Gómez, C. (2015). Más allá de un boom de recursos naturales: efectos de los choques petroleros en la economía colombiana. Recuperado de https://ideas.repec.org/p/col/000089/012565.html

Gómez, V., \& Maravall, A. (2001). Seasonal adjustment and signal extraction in economic time series. A course in time series analysis, 202-246.

González, S. y Hernández, E. (2016). Impactos indirectos de los precios del petróleo en el crecimiento económico colombiano. Lecturas de Economía, 84, 103-141.

Hernández, G. (2013). Colombia: Términos de intercambio y fluctuaciones de la producción. Revista CEPAL, (110), 109-131.

Izquierdo, A., Romero, R., \& Talvi, E. (2008). Booms and busts in Latin America: the role of external factors. Banco Interamericano de Desarrollo, (631), 1- 31.

Jenkins, R. O. (2011). The "China effect" on commodity prices and Latin American export earnings. CEPAL Review, (103), 73- 87.

Franco, O., Mayorga, M. Y., \& Magrinyà, F. (2019). Aproximación a una adaptación metodológica del índice de desarrollo humano país-municipio. Para los municipios de la provincia del Guayas-Ecuador 2001-2010. Espacios, 40(1), 16-25. 
Mendoza, E. G. (1995). The terms of trade, the real exchange rate, and economic fluctuations. International Economic Review, 36(1), 101-137.

Oviedo-Gómez, A., Candelo-Viafara, J. M. (2020). Mining and Energy Commodity Price Effects on Colombian Economy. Cuadernos de Administración, 36(67), 93-108. https://doi.org/10.25100/cdea. v36i67.8641

Oviedo-Gómez, A. F., \& Sierra, L. P. (2019). Importancia de los términos de intercambio en la economía colombiana. Revista CEPAL, (128), 125-154. Recuperado de https://repositorio.cepal.org/ bitstream/handle/11362/44740/1/RVE128_Oviedo.pdf

Parra, J. C. (2008). Hechos Estilizados de la Economía Colombiana: Fundamentos Empíricos para la Construcción y Evaluación de un Modelo DSGE. Borradores de Economía. Banco de la República, (509), 1-47.

Peláez, J. T., \& Sierra, L. P. (2016). Does Industrial Employment React to Movements in the Real Exchange Rate? An Empirical Analysis for Colombia, 2000-2010. Latin American Journal of Economics, 56(1), 36-39.

Peña, C. (2008). Choques petroleros, incertidumbre e inversión privada. Venezuela, 1968-2007. Perfil de Coyuntura Económica, (11), 51-74.

Peña, C. (2015). Desempleo, inversión y términos de intercambio. Venezuela 1970-2012. Perfil de Coyuntura Económica, (25), 141-163.

Pesaran, H. H., \& Shin, Y. (1998). Generalized impulse response analysis in linear multivariate models. Economics letters, 58(1), 17-29.

Phillips, P. C., \& Perron, P. (1988). Testing for a unit root in time series regression. Biometrika, 75(2), $335-346$.

PNUD. (2014). Informe sobre Desarrollo Humano 2013. El ascenso del Sur: Progreso humano en un mundo diverso. México: Union de Naciones Unidas.

Poncela, P., Senra, E. y Sierra, L. P. (2017). Long-term links between raw materials prices, real exchange rate and relative de-industrialization in a commodity-dependent economy: empirical evidence of "Dutch disease" in Colombia. Empirical Economics, 52(2), 777-798.

Schmitt-Grohé, S., \& Uribe, M. (2015). How Important Are Terms Of Trade Shocks? National Bureau of Economic Research, (w21253), 1-37.

Sierra, L., \& Manrique, L. (2014). Impacto del tipo de cambio real en los sectores industriales de Colombia: una primera aproximación. Revista CEPAL, (114), 127-143.

Sims, C. A. (1980). Macroeconomics and reality. Econometrica: journal of the Econometric Society, 1-48. https://www.jstor.org/stable/1912017

Sinnott, E., Nash, J., \& De la Torre, A. (2010). Natural resources in Latin America and the Caribbean: beyond booms and busts? World Bank Publications.

Spatafora, N., \& Warner, A. M. (1999). Macroeconomic and sectorial effects of terms-of-trade shocks: the experience of the oil-exporting developing countries. Washington: Estados Unidos. IMF.

Stock, J. H., \& Watson, M. W. (2002). Macroeconomic forecasting using diffusion indexes. Journal of Business \& Economic Statistics, 20(2), 147-162.

Stock, J. H., \& Watson, M. W. (2005). Implications of dynamic factor models for VAR analysis. National Bureau of Economic Research, 11467, 1-67.

Stock, J. H., \& Watson, M. W. (2011). Dynamic factor models. Oxford handbook of economic for recasting, 1, 35-59.

The World Bank Grupo. (2016). World Development Indicators: Exports of goods and services (\% of GDP). Recuperado de: http://databank.worldbank.org/data/reports.aspx?Code=NE.EXP.GNFS. ZS\&id=af3ce82b\&report_name=Popular_indicators\&populartype=series\&ispopular=y

Uribe, J. \& Ulloa, I. (2011). Otro país exportador neto de petróleo y sus reacciones macroeconómicas ante cambios del precio: Colombia [Documentos de Trabajo, 140]. Cali: Universidad del Valle. Recuperado de http://cms.univalle.edu.co/socioeconomia/media/ckfinder/files/DOCUMENTO\%20 DE\%20TRABAJO \%20CIDSE\%20N\%C2\%B0\%20140.pdf

Vargas, H. (2015). Choques macroeconómicos y retos de la política monetaria 2014-2015. Serie: Discursos y presentaciones, Banco de la República. 1-20. 


\section{APPENDIX A}

Table A1 contains the information on the number of lags according to the selection criteria for the estimated models. Finally, two lags were used since for this value the model is robust and consistent in the evaluation of the assumptions about residuals. On the other hand, Table A2 shows the self-correlation test (LM test) on the residuals for the estimated models.

Table A1: Selection criteria lags

\begin{tabular}{|c|c|c|c|c|c|c|}
\hline \multirow{2}{*}{ Oil prices model } & Criteria & LR & FPE & AIC & SC & HQ \\
\cline { 2 - 7 } & Number of lags & 2 & 2 & 5 & 0 & 0 \\
\hline \multirow{2}{*}{ Coffee prices model } & Criteria & LR & FPE & AIC & SC & HQ \\
\cline { 2 - 7 } & Number of lags & 2 & 5 & 5 & 0 & 0 \\
\hline \multirow{2}{*}{ Coal prices model } & Criteria & LR & FPE & AIC & SC & HO \\
\cline { 2 - 7 } & Number of lags & 1 & 1 & 5 & 0 & 0 \\
\hline \multirow{2}{*}{ Nickel prices model } & Criteria & LR & FPE & AIC & SC & HO \\
\cline { 2 - 7 } & Number of lags & 2 & 5 & 5 & 0 & 0 \\
\hline
\end{tabular}

LR: likelihood ratio test; FPE: Final Prediction Error; AIC: Akaike information criteria; SC: Schwarz information criteria; Headquarters: Hannan-Quinn information criteria.

Source: Authors' own elaboration.

Table A2: Autocorrelation test (LM test)

\begin{tabular}{|c|c|c|c|c|c|c|c|c|}
\hline & \multicolumn{2}{|c|}{ Oil prices model } & \multicolumn{2}{c|}{ Coffee prices model } & \multicolumn{2}{c|}{ Coal prices model } & \multicolumn{2}{c|}{$\begin{array}{c}\text { Nickel prices } \\
\text { model }\end{array}$} \\
\hline Lag & LM-Stat & p-valor & LM-Stat & $p$-valor & LM-Stat & $p$-valor & LM-Stat & $p$-valor \\
\hline 1 & 69.55808 & 0.2959 & 54.90316 & 0.7841 & 50.85209 & 0.8835 & 4.90316 & 0.7841 \\
\hline 2 & 56.51396 & 0.7356 & 75.22208 & 0.1593 & 61.43872 & 0.5676 & 5.22208 & 0.1593 \\
\hline 3 & 55.28074 & 0.7731 & 60.61244 & 0.5970 & 60.99059 & 0.5836 & 60.61244 & 0.5970 \\
\hline 4 & 59.45368 & 0.6377 & 69.22109 & 0.3057 & 50.21566 & 0.8959 & 9.22109 & 0.3057 \\
\hline 5 & 86.34082 & 0.0329 & 82.31391 & 0.0613 & 86.29408 & 0.0331 & 2.31391 & 0.0613 \\
\hline
\end{tabular}

Note: null hypothesis: there is no correlation in the residuals.

Source: Authors' own elaboration. 